\title{
"THE IMPACT OF THE COVID-19 PANDEMIC ON THE ECONOMIC ACTIVITY OF THE REPUBLIC OF NORTHERN MACEDONIA"
}

\author{
Mahije Mustafi \\ "Pjeter Budi" College, Bussiness Administration Department, Lecturer, Prishtina, Kosovo \\ mahijemustafi@hotmail.com, Belicica, 124, Gostivar, Macedonia \\ Sulbije Memeti Karemani \\ "Pjeter Budi" College, Bussiness Administration Department, Lecturer, Prishtina, \\ Kosovo, sulbijememeti@live.com, Reçica e Madhe, Tetove, Macedonia
}

\begin{abstract}
COVID-19 not only endangers human health but also hits hard on the economy. Isolation and paralysis of public life hits the economies of every country. Before analyzing the links between COVID-19 and the possible economic crisis, we can say that the crises in capitalism are inherent and the virus should be seen as a spark which accelerates the turbines that shake the system.
\end{abstract}

However, while insufficient to predict the extent of the damage that COVID-19 could do to the economy, this starting point is sufficient to anticipate the chain effects. The immediate effect of all these restrictions is the decline in economic activity, which results in declining production and rising prices. We can say that there is a direct cause-andeffect correlation between the virus and the crisis.

The economy of the Republic of Northern Macedonia has been hit hard by the Covid 19. pandemic. These six months have paralyzed almost all sectors of the economy in the country. Government aid packages were more social while those for business still remain unused.

Companies in northern Macedonia have already been severely affected. The closure of many businesses is accompanied by the dismissal of many workers, which is also associated with a social crisis. Growth in the country for 2020 is projected to be between -1.4 and -3.2 percent - which provides a baseline and unfavorable scenario due to the high uncertainty brought about by the pandemic.

In Northern Macedonia, improving governance and strengthening institutions are longterm policies that can address the main causes of continued emigration, in order to maintain a skilled workforce. This can be achieved by accelerating job creation, promoting the private sector, investing in higher education and increasing opportunities for women in the economy.

The capital of the diaspora influences the maintenance of social stability and the reduction of poverty in Macedonia and in the future the state should take it more seriously the investments of the diaspora.

Weak administrative capacity can cancel the implementation of reforms as well as large critical projects implemented with state guarantees. Political instability and insufficient reform progress could reduce investor confidence.

Northern Macedonia's accession to NATO and the official invitation of the EU Council to open negotiations for EU membership should help accelerate the recovery.

Keywords: COVID-19, R. of Northern Macedonia, economic activity, measures. 


\section{Introduction}

On February 26, 2020, Northern Macedonia confirmed the first case of Coronavirus in the country. On March 10, 2020, all kindergartens and other institutions closed for 14 days. Due to new cases with Covid-19 on $16^{\text {th }}$ of March 2020, the Government decided to close all border crossings for the passage of foreign nationals, passengers and vehicles, except for the entry and transit of trucks, diplomatic corps and others for which the Ministry of Interior will receive a preliminary opinion from the Crisis Staff. The International Airport in Skopje also got closed, with the exception of military, state, cargo, medical, humanitarian and unmanned aircraft. "On March the $19^{\text {th }}, 2020$, the Republic of Northern Macedonia declared a state of emergency. The President of Northern Macedonia, Stevo Pendarovski, decided not to continue the state of emergency, which ends on June 13, paving the way for early parliamentary elections, which were held on July 15. The electoral campaign of the political parties in Northern Macedonia took place mainly on social networks, or in small informative gatherings, based on the protocol approved by the Commission of Infectious Diseases.

COVID-19 not only endangers human health but also hits the economy hard. Isolation and paralysis of public life hits the economies of every country. Before analyzing the links between COVID-19 and the possible economic crisis, we can say that the crises in capitalism are inherent and the virus should be seen as a spark which accelerates the turbines that shake the system.

However, while insufficient to predict the extent of the damage that COVID-19 could do to the economy, this starting point is sufficient to anticipate the chain effects. The immediate effect of all these restrictions is the decline in economic activity, which results in declining production and rising prices. We can say that there is a direct cause-and-effect correlation between the virus and the crisis.

COVID-19 will also be a negative shock in demand where governments will have the main burden of stabilization starting from making decisions that directly affect health systems to creating safety nets for the affected. As less tax revenue was generated, they were forced to make hasty decisions that could not meet all the requirements.

Uncertainties about the effectiveness of monetary policy pay attention to fiscal policy. Governments of all countries faced declining revenues due to the slowdown in economic activities, which used public finances.

Even in the Republic of Northern Macedonia this resulted in the loss of many jobs and the closure of many businesses. Workers suffered more from the loss due to the jobs they do and are not valued and small businesses as well. The effect of a future crisis could be even more dangerous. COVID-19, as a random and unpredictable event, had a negative impact on supply, adding to uncertainties about the future, where this shock affected investor bounce and investment decline. Northern Macedonia's accession to NATO, and official EU Council invitation to open EU membership negotiations should help accelerate recovery. Social schemes were built which will protect citizens who lost their jobs and whose incomes were reduced. Their financing required fiscal stimulus packages, which were partly financed by funds provided by financial organizations such as the World Bank and the International Monetary Fund.

Some of the measures that have been taken are: allocation of special funds for pandemic management, extension of tax filing and loan repayment deadlines (in cooperation with central banks), creation of compensation schemes for workers, the possibility of direct transfer of money to citizens.

The economy of the Republic of Northern Macedonia has been hit hard by the Covid 19 pandemic. These six months have paralyzed almost all sectors of the economy in the country. Government aid packages were more social while those for business still remain unused.

The market is unable to regulate many of the issues that occur within it, much less the issues that are out of it. Fiscal policy support is essential to help the private sector overcome the COVID-19 crisis, but the RNM has little fiscal room for new measures.

The government of the country throughout the process should work on stimulating demand, which will take more time. 


\section{"Only one crisis - real or perceived - produces real change." \\ Milton Friedman}

The coronavirus has disrupted many economic sectors, leaving businesses without revenue "while the liabilities of these businesses are active, which could push them to failure." The decline in economic activity in the country is undoubtedly expected to affect consumption.

The private sector also has a very sensitive structure in development, is dependent on foreign markets and the economic downturn significantly affects businesses.

A large number of businesses remain closed or with a minimum capacity for several months, where crisis management became even more difficult and all sectors were affected in a chain reaction. A number of businesses stopped operating in accordance with government decisions. As measures that were initially taken by some of the businesses were to reduce their operating expenses and stop nonmandatory activities, some of the companies switched to the online platform, some of the investment projects were suspended. Due to lack of demand and lack of revenue, some of the enterprises were closed. The closure of many businesses is accompanied by the dismissal of many workers, which is also associated with a social crisis.

According to the latest World Bank (REI) regular economic report, growth in the country for 2020 is projected to be between -1.4 and -3.2 percent - which provides a baseline and unfavorable scenario due to the high uncertainty posed by the pandemic.

\section{Methodology}

In order to analyze and to give a correct conclusion about the topic will analyze the integration of the Republic of Macedonia in the European Union over the years, the causes and consequences. Amongt the methods that we have used in preparing this paper has been monitoring and analyzing the details of the country integration. The paper used qualitative methods and descriptive research.

\section{The effects of the crisis on the economy of the Republic of Northern Macedonia}

The first support measures for the economy were announced in the third week of March, at a press conference of the SDSM Party, by Prime Minister Zoran Zaev to protect the economy hit by the coronavirus.

The announced measures were the subject of much criticism. The first criticism related to the fact that they were announced by a leader of a political party in a press conference, which was evaluated as a populist move aimed at gaining political points for SDSM. The second criticism focused on proposals to reduce salaries in the public sector, which has over 100,000 employees. Economic experts have warned that these cuts will further affect consumer confidence and reduce already reduced demand, thus causing harmful effects on the economy as a whole.

The first measure has to do with the provision of direct financial assistance ( $€ 5.7$ million made available by the country's Development Bank) to support the liquidity of micro, small and medium-sized companies, whose economic activity has been mostly affected.

The total value of economic measures taken by the government the first and the second package is 200250 million euros or $2 \%$ of GDP. At the 54th meeting, the Government of the Republic of Northern Macedonia reviewed and approved the third package of economic measures for the revival of the Macedonian economy through direct support to citizens and the economy under COVID-19.

These are measures for a new, developing economy of the Macedonian economy, through which it will affect consumption and stimulate the protection, promotion and growth of the country's economy and 
increase competitiveness, both in the region and beyond. The total value of the three packages approved by the government amounts is up to 550 million euros or 5-5.5 of GDP.

It is important that the economy is stimulated and that the funds that are provided are well managed responsibly and transparently, in order to go directly in favor of the ones in need, the unemployed and the entrepreneurs facing difficulties, to easy the costs. The government should also pay attention to the drafting of social policies, because the increase in unemployment affects the economic development of the country. Many people who lose their jobs find themselves stressed and in an extremely aggravated psychological situation. Poverty and difficult situations can be truly fatal and threaten public peace.

The unprecedented Covid-19 shock has also created stress in the capital markets, prompting a vigours reaction from central banks.

\section{How much did these measures have an effect on the economy?}

In recent years, averages of $40 \%$ of exports and $60 \%$ of imports have been made through small and medium enterprises, which have been effected way too much by this crisis. This means that the crisis also represents a threat to the trade deficit, which is mainly covered by exports, an important category in the balance of payments. Another problem that worsened even more is the slowdown in freight transport, with delays across borders, despite the fact that freight transport is released from the usual travel bans imposed by countries in Europe and the region. State Statistical Office, the total value of exports of goods from the Republic of Northern Macedonia in the period January - June 2020 reached $151,054,307$ thousand denars and decreased by $22.2 \%$ compared to the same period last year.

The value of imported goods in the period January - June 2020 achieved up to 206239277 thousand denars, which is $17.9 \%$ less compared to the same period last year. According to previous data from the State Statistical Office, the total value of exports of goods from the Republic of Northern Macedonia in the period January - June 2020 is up to $151,054,307$ thousand denars and decreased by $22.2 \%$ compared to the same period last year.

The growth rate of gross domestic product (GDP) for the first quarter of 2020 is $0.2 \%$, which is a very low growth. Considering the effects of the crisis in the following periods, it is expected that the country will lose even more from this indicator.

The industrial production index in June 2020, compared to June 2019, was 84.9. The decline is evident in all sectors of the industry

Public debt in the second quarter of 2020 is $59.5 \%$, while government debt is $50.7 \%$. The increase in public and government debt in the second quarter is mainly due to the withdrawal of funds through the Eurobond and loans from the International Monetary Fund, in order to provide liquidity during the crisis of COVID-19, to provide funds for the implementation of anti-crisis measures and smooth execution of the budget despite the crisis, ie covering the increased deficit due to declining revenues as a result of the COVID crisis.

Budget revenues in the period January - May 2020 amounted in 73,388 million denars, ie 10.9\% of GDP, which is lower by $8.9 \%$ compared to the same period of 2019; The total budget expenditures for the period January - May 2020 amounted to 92,291 million denars, ie $13.7 \%$ of GDP, which is $7.9 \%$ more compared to the same period of 2019.

The Minister of Finance, Nina Angellovska in one of the regular press conferences regarding the monthly execution of the Budget, which were held for the purpose of high transparency since the beginning of the crisis caused by COVID-19, stressed that the collection of revenues in the month of June is significantly better than they were predicted, indicating that the reopening of the economy will be faster than expected. For June, revenue collection compared to last year is lower by $9.6 \%$, which is an improvement compared to the previous two months.

There is also an excess of certain obligations for higher percentages compared to last year, such as personal income tax and contributions. 
According to the study of the World Bank, enterporises in Northern Macedonia have already beeneffected way too much. The Finance Survey found that about 41.5 percent of businesses were forced to close due to precautionary measures and 43.1 percent of businesses are expecting a significant drop in revenue.

Migration also raises concerns about the 'brain drain' of skilled workers from the country, as more educated individuals tend to emigrate. Individuals with higher education represent approximately $40 \%$ of the emigrant population from Northern Macedonia.

Remittance revenues in the RMV in 2019 were 317 million euros, where the share in GDP was $2.5 \%$. The decline in remittances due to measures taken by the countries where they are located further deepened the economic recession.

The Republic of Northern Macedonia has a better business climate in the region, and also has lower fiscal risks compared to other countries. These are the main points for our country in the OECD report on the countries of the Western Balkans ("Government at a glance: Western Balkans 2020"). The report notes that the country is a regional leader in providing a favorable business climate and has better results in relation to the average of OECD countries and the average of OECD countries which are EU members.

The outbreak of COVID-19 in July and August and if it continues in the upcoming months, if accompanied by the necessary isolation measures will further increase economic uncertainty as well as economic and social costs.

\section{Conclusion}

The main risk for Northern Macedonia is that a prolonged pandemic combined with a deeper recession in the EU could make it increasingly difficult to manage the economic crisis.

We are lucky that we can not experiment, but it is enough to adapt the legislation with the countries of the European Community, reducing the role of the Government and increasing the role of the citizen, which is part of the market economy. The longer the isolation period, the more difficult the state of the economy becomes.

Keeping the pandemic under control is very important, in order to get back to normal and resume production.

The prolongation of the crisis affects investors' risk-averse behavior and consequently borrowing costs, which would have significant fiscal costs for the Western Balkan countries with high external debt to GDP ratios

Firms in Northern Macedonia have already been severely affected. The closure of many businesses is accompanied by the firing of many workers, which is also associated with a social crisis. In Northern Macedonia, improving governance and strengthening institutions are long-term policies that can address the root causes of continued emigration, in order to maintain a skilled workforce. This can be achieved by accelerating job creation, promoting the private sector, investing in higher education and increasing opportunities for women in the economy.

The capital of the diaspora influences the maintenance of social stability and the reduction of poverty in Macedonia and in the future the state should take more seriously the investments of the diaspora.

Weak administrative capacity can cancel the implementation of reforms as well as large critical projects implemented with state guarantees. Political instability and insufficient reform progress could reduce investor's confidence. 


\section{References}

[1] Byrda,M \& Wyploz,Ch. Macroeconomics, 7th Edition, Europian Text. United States: Oxford University Press.

[2] N.Gregory Mankiw, Principles of Economics 8th Edition

[3] https://china-cee.eu/2020/04/16/north-macedonia-economy-briefing-the-economic-contagionof-covid-19-early-shocks-and-measures/

[4] https://meta.mk/nema-dilemi-korona-virusot-\%D1\%9Ce-ima-dramatichni-poslediczi-vrz ekonomi\%D1\%98ata/?fbclid=IëAR1ZSPVmIYtTTTcE49sMsn1DAQnDXv A617GËgMëq Rrf835Gdl58xMqedTY

[5] "North Macedonia's businesses fear pandemic's economic shockwaves" available at: Ihttps://balkaninsight.com/2020/03/18/north-macedonias-businesses-fear-pandemicseconomic-shockwaves/

[6] "The corona virus wiill cause a fall in the industry in Macedonia" available at:https://www.mkd.mk/makedonija/ekonomija/koronavirusot-predizvikuva-pad-voindustrijata-i-vo-makedonija-predupreduva

[7] "The government will help the business sector" available at: https://republika.mk/vesti/ekonomija/spasovski-vladata-kje-mu-pomogne-na-biznis-sektorot/

[8] http://documents1.worldbank.org/curated/en/444031591289647448/pdf/The-Economic-andSocial-Impact-of-COVID-19-Private-Sector.pdf

[9] http://pubdocs.worldbank.org/en/535681588144292411/WB-RER17-The-Economic-andSocial-Impact-of-COVID-19-Setting-the-stage-\%D0\%9C\%D0\%9A.pdf

[10] Finance.gov.mk 